\title{
TRADUÇÕES NA AMÉRICA PORTUGUUESA: AS BIBLIOTECAS DOS REVOLUCIONÁRIOS BRASILEIROS
}

\author{
Irene Hirsch $\dagger$
}

RESUMO: A presença de traduções em dois movimentos de revolta que antecederam a Independência do Brasil será examinada neste artigo. A Inconfidência Mineira e a Inconfidência Baiana, dois dos principais eventos de contestação do período colonial brasileiro, contemporâneos das Revoluções Americana e Francesa, além de refletir a insatisfação com as condições locais e apontar para o colapso da antiga ordem, dialogaram com as ideias que circulavam internacionalmente. O escrutínio das bibliotecas do período é revelador dessa articulação.

UNITERMOS: Inconfidência mineira; Inconfidência baiana; bibliotecas particulares; Revolução norte-americana; Revolução francesa.

ABSTRACT: In this article I shall examine the presence of translations in two rebel movements which preceded the independence of Brazil. The Minas Conspiracy and the Bahia Conspiracy, two of the most important protest movements in the Brazilian colonial period, contemporary with the American and French Revolutions, in addition to reflecting the dissatisfaction with local conditions and pointing to the collapse of the old order, dialogued with ideas that circulated internationally. An examination of the libraries of the period shows the importance of the revolutionary ideas.

$\dagger$ In memoriam. 
KEYWORDS: Minas Conspiracy; Bahia Conspiracy; private libraries; American Revolution; French Revolution.

\section{Introdução}

Os estudos de textos filosóficos e de textos constitutivos das repúblicas latino-americanas demonstram que a tradução cumpriu um papel importante à época da independência das colônias. Bastin, em sua análise dos textos traduzidos na América Espanhola, particularmente na Venezuela, comprova a importância de tradutores, como Francisco de Miranda, por exemplo, no processo de emancipação das colônias. A insuficiência de estudos sobre as traduções no período colonial brasileiro pode ser entendida como um dos efeitos perversos da proibição de imprensa imposta por Portugal, que fez com que textos publicados ou manuscritos fossem raros, dificeis de serem encontrados. Como se sabe, a Imprensa Régia e as primeiras tipografias só surgiram após a chegada da família real ao Brasil, em 1808. A ilegalidade de publicações, no entanto, não impediu que os movimentos insurgentes se alimentassem da discussão política contemporânea, que buscava um fim para a antiga ordem. Textos impressos, manuscritos, de prosa ou poesia, serviam de suporte para as reuniões dos insurgentes mineiros e baianos. Documentos como a Declaração de Independência norte-americana e as constituições das 13 colônias foram traduzidos, especialmente para o francês, algumas semanas depois de divulgados. Cópias em inglês, francês ou outro idioma, foram parar nas mãos de ideólogos da Alemanha, Áustria, Suíça, Espanha, México, Venezuela, Argentina e, também, do Brasil.

No entanto, alguns textos, como certas traduções manuscritas, muitas vezes foram destruídos pelos próprios insurgentes, que, ao serem avisados da iminente repressão por parte das autoridades, destruíam as provas que poderiam incriminá-los. Sua existência, no entanto, é relatada nos depoimentos dos autos da devassa.

Tampouco se pode minimizar a importância da oralidade como suporte para a divulgação das ideias dos revoltosos. Eram

TradTerm, 17, 2010, p. 31-43 
conhecidas as reuniões, nas quais além de literatura, discutiamse as novas ideias vindas da Europa, configurando-se em uma forma de tradução ou interpretação.

Nesse artigo abordarei dois movimentos de revolta que antecederam a Independência do Brasil, dois dos principais eventos de contestação do período colonial, a Inconfidência Mineira e a Inconfidência Baiana, com a hipótese de que a tradução desempenhou um papel importante na propagação das ideias revolucionárias. Os dois movimentos, contemporâneos das Revoluções Americana e Francesa, foram de ação contestatória anticolonialista, refletindo a insatisfação com as condições locais e apontando para o colapso da antiga ordem, ao buscar alternativas nas novas formas de organização do Estado. Não poderiam ter sido impermeáveis ao pensamento coevo dos enciclopedistas.

Bastin propõe uma divisão da História da Tradução na América Latina, constituída de cinco momentos: 1. Encontro e Conquista, 2. Período Colonial, 3. Pré-independência, 4. Independência e República, 5. 1920 - data atual (2004a). Adotando essa periodização, situarei esta pesquisa no terceiro período, o da pré-independência, por tratar das traduções que circularam durante as Inconfidências Mineira e Baiana, precursoras do movimento de Independência. Muito embora a Independência do Brasil tenha tido uma configuração própria diferente dos países da América Espanhola, por inaugurar uma monarquia e não uma república, os documentos filosóficos e as ideias constitucionalistas que circularam entre a população insatisfeita com a metrópole eram as mesmas por toda parte, ou seja, as dos filósofos iluministas.

Dentre os movimentos revoltosos que antecederam a Independência, historiadores destacam as manifestações de contestação que ocorreram em Minas Gerais, Bahia, Pernambuco e Rio de Janeiro, entre os anos 1789 e 1801, todos se caracterizando por serem movimentos de desapreço à colônia portuguesa, movimentos de rebeldia expressos em saques e motins. No entanto, apenas os acontecimentos de Minas Gerais (1789) e da Bahia (1798) foram insurreições, "na medida em que nestes se tratava de deliberada e organizada vontade de subverter a or- 
dem pública e os padrões de organização do Estado" (Jancsó, 1997: 390). Separados apenas por uma década, os dois movimentos se coloriram de matizes diferentes; enquanto que os acontecimentos de Minas Gerais foram informados pelos textos ilustrados franceses e ingleses, ou seja, a liberdade não era pensada como a supressão das desigualdades, na Bahia, a dimensão política provinha da França revolucionária (Jancsó, 1997: 422). Em outras palavras, a insurreição baiana foi posterior à Revolução Francesa, o que resultou em uma radicalização nas posturas dos insurgentes.

\section{A tradução em Minas Gerais}

Havia poucas bibliotecas particulares na colônia até o século XIX, e um número reduzido de pessoas era proprietária de livros, que se limitava a uns poucos títulos, em geral, de cunho religioso ou ligados às suas profissões. Destacam-se entre os principais proprietários de livrarias clérigos, advogados, médicos e funcionários públicos dos altos escalões (Villalta, 1997: 383). Abordarei menos as bibliotecas ligadas aos oficios de seus proprietários, concentrando-me sobre as que tinham livros proibidos que, a partir do século XVIII, eram obras afinadas com as mudanças culturais, mais especificamente, com a ilustração, escritas em língua francesa ou inglesa. A natureza contestatória dessas obras constitui-se na maior dificuldade desse estudo: como referido, ao saberem da chegada da repressão, os próprios revoltosos se desfaziam de provas que poderiam incriminálos, destruindo livros, cópias e transcrições e traduções manuscritas.

A Inconfidência Mineira, como se sabe, foi uma conspiração em Minas Gerais desmantelada em 1789, sendo os acusados presos ou exilados, e Joaquim José da Silva Xavier, o Tiradentes, a figura central, executado em praça pública.

Grande parte de nosso conhecimento sobre o movimento é uma construção apoiada nos testemunhos e nas listas de bens confiscados dos insurgentes. Diferentes perspectivas procuraram explicar os motivos dos inconfidentes e vários estudiosos descreveram-nos como sendo membros de uma elite de inte-

TradTerm, 17, 2010, p. 31-43 
lectuais idealistas que almejavam a emancipação politica, enquanto que outros pesquisadores acreditavam tratar-se de colonizadores corruptos e endividados que queriam a insurreição para resolver suas dividas pessoais (Mello e Souza in Novaes, 2006: 362).

Pesquisas sobre a presença de livros em Minas Gerais à época da Inconfidência mostram que a biblioteca do bispo de Mariana, Dom Frei Domingos da Encarnação Pontével, com 412 títulos e 1066 volumes, era a maior de todo período colonial. No entanto, os livros iluministas se faziam presentes em maior número na biblioteca do cônego Luís Vieira da Silva, considerada a mais revolucionária. Desaparecida desde a revolta, tinha 241 títulos e 556 volumes. Outras bibliotecas importantes do período colonial mineiro foram as de Cláudio Manuel da Costa, com 99 títulos e 344 volumes, do padre Carlos Correia de Toledo, com 60 títulos e 105 volumes; do padre Manuel Rodrigues da Costa, com 59 títulos e 207 volumes; do coronel José Resende Costa, com 20 títulos e 61 volumes; de Domingos Fernandes da Cruz, com sete títulos e 18 volumes; do coronel Inácio José de Alvarenga Peixoto, com quatro títulos e 18 volumes e do coronel José Aires Gomes, com quatro títulos e quatro volumes (Villalta, 2006: 372-3).

O exame da biblioteca do cônego Luís Vieira da Silva, um dos mais eruditos ativistas, revela que mais da metade dos livros estavam escritos em latim, cerca de 90 em francês, mais de 30 em português, cinco ou seis em italiano, o mesmo número em espanhol e 24 em inglês (Frieiro, 1957: 28).

Uma relação dos livros foi elaborada pelo barão Homem de Melo e pelo padre José Marcondes e transcrita na Revista do IHGB. Fizeram uma divisão dos livros do cônego em cinco categorias: Livros Sagrados, Teológicos e Canônicos, Livros de História, Livros de Jurisprudência, Livros de Ciências, Livros de Literatura (ADIM vol. 11, 2001: 50). Para essa pesquisa, importa destacar as traduções, especialmente para o francês. Dentre os livros em francês, encontravam-se importantes historiadores e filósofos britânicos, como Hume e Robertson, em traduções: de Hume havia a Histoire de la Maison d'Autriche, em seis volumes e a Histoire de la Maison des Tudor, também em seis volumes. 
De Robertson, a Histoire d'Écosse, em três volumes, a Histoire du Règne de l'Empereur Charles-Quint, em seis, e a Histoire de l'Amerique, em quatro. Também em francês, em sua grande maioria, havia dicionários, tratados de Física, Geometria, Astronomia, História Natural, Geografia, Agricultura, Artes Militares, além de livros de Medicina, Filosofia, Metafísica, Lógica e os clássicos portugueses e pensadores da Antiguidade clássica. Outras traduções encontradas na biblioteca do cônego foram as obras de Metastasio e de Aurelio Bertola de Giorgi em francês e a Ars Poetica de Horácio em português, traduzida por Francisco José Freire (Frieiro, 1957: 41-3).

Observa-se, portanto, que a biblioteca do cônego era constituída em grande parte por traduções, que informavam o universo cultural dos poetas árcades e mentores da revolução. Infelizmente, no entanto, a biblioteca desapareceu por completo, restando apenas a relação dos livros, posteriormente.

\section{Documentos confiscados}

Um importante documento desaparecido é a tradução de A riqueza das nações de Adam Smith, que supostamente foi feita e comentada por Cláudio Manoel da Costa, um dos líderes da revolta e poetas mais importantes, que também traduziu peças de Metastasio (Maxwell, 1995: 147; Rouanet in Novaes, 2006: 330). Joaquim Norberto, o famoso historiador do século XIX, comenta que Cláudio Manoel da Costa foi o primeiro escritor português a discutir a nova ciência política e que "o manuscrito foi apreendido com outro inédito seu e teve o sumiço que o fisco real achou conveniente dar-lhe" (Souza e Silva, 1911: 68).

Outro livro dos Inconfidentes que foi confiscado é uma tradução para o francês de documentos e das constituições norteamericanas, o Recueil des Loix Constitutives des États-Unis de l'Amérique. Organizado por Claude Ambroise Regnier, possivelmente foi extraido de Les Affaires de l'Amérique et de l'Angleterre, uma publicação europeia que trazia informações sobre a Revolução Americana. Segundo Rocha (2007), o Recueil é uma versão resumida dos Affaires. Trata-se de uma compilação das constituições de seis dos treze Estados Confederados e da Declaração

TradTerm, 17, 2010, p. 31-43 
de Independência, redigida por Thomas Jefferson; ou seja, é um documento baseado nos princípios do Iluminismo transformados em leis, com as ideias desenvolvidas Locke, Montesquieu, Rousseau e Adam Smith. Essa coletânea foi impressa clandestinamente em 1778, provavelmente em Paris, apesar de a indicação da capa ser a Suíça, e apenas dois exemplares terem chegado no Brasil colonial, sendo que só um sobreviveu e hoje é uma das peças mais importantes do Museu da Inconfidência em Ouro Preto.

O livro teria sido trazido para o Brasil por José Álvares Maciel, que o teria presenteado a Tiradentes, e se tornaria parte das obsessões do alferes e do cônego Luiz Vieira. Segundo Tarquínio J. B. de Oliveira - o tradutor para o português do Recueil-, Tiradentes utilizava um sistema de propaganda revolucionário com seu livro: simulando necessitar da tradução de alguns trechos da obra, deixava-a com o tradutor a quem pedira o favor, para que, por meio da leitura feita, ele entrasse em contato com o teor da obra, na esperança de que este viesse se juntar aos inconfidentes (ADIM vol. 3, 1980: 10).

O Recueil é uma prova concreta de que por meio da tradução se deu a repercussão dos acontecimentos na América Inglesa. As bibliotecas e o empréstimo de livros são outra evidência de que os sediciosos estavam informados das novidades. No entanto, há que se ressaltar a importância da circulação de ideias no período colonial por meio de reuniões e conversas secretas no restrito âmbito doméstico: os casamentos, os funerais, os batizados, os saraus, as tertúlias eram ocasiões propícias para se discutir as novas ideias, a ponto de o mote do levante de 1789 ter sido "Tal é o dia do batizado" (Souza, 1997: 443).

\section{A tradução na Bahia}

A Revolta de Búzios, Revolta dos Alfaiates ou Inconfidência Baiana de 1798 foram marcos na luta pela independência, que planejou romper os laços de dominação de Portugal sobre a Bahia. Assim como os acontecimentos de Minas Gerais, que revelaram a insatisfação contra a metrópole de diferentes setores da sociedade, que se expressava na crítica aos comentários de 
textos proibidos, chegando até a articulação de um movimento mais amplo incitando o povo ao levante. Como em Minas, à insatisfação com a metrópole acrescentaram-se as ideias libertárias dos enciclopedistas.

A Inconfidência Baiana de 1798 contou com a participação de pessoas de origem social de amplitude não encontrada em nenhuma das outras manifestações da crise política do sistema. Segundo Jancsó, a Revolução dos Alfaiates representou uma tentativa inusitada no período colonial: "a busca da integração do conjunto da população, por cima das diferenças de riqueza, privilégios, origem e cor, em torno de um projeto de luta política" (Jancsó, 1996: 33). Trinta e três homens foram acusados, sendo que dez eram simples artesãos; dezesseis não tinham bens, encontrando-se oito provavelmente nas mesmas condições; nove deles eram escravos. Dentre esses homens de condição social bastante precária, destacavam-se Luiz Gonzaga das Virgens, soldado granadeiro; Lucas Dantas d'Amorim Torres, soldado de artilharia; João de Deus do Nascimento, alfaiate cabo da esquadra e Manoel Faustino dos Santos Lira, também alfaiate. Ao lado deles, figuravam pessoas de origem social mais abastada, como Cipriano José Barata d'Almeida, cirurgião, bacharel em filosofia pela Universidade de Coimbra e seu irmão José Raimundo Barata D’Almeida; Francisco Moniz Barreto d'Aragão, professor de Gramática Latina e Hermógenes Francisco de Aguilar Pantoja, tenente do $2^{\circ}$ regimento da linha.

Quanto às bibliotecas, o padre Francisco Agostinho Gomes foi o proprietário da maior biblioteca particular do fim do século XVIII na Bahia, constituída de milhares de livros, entre eles as obras de Lavoisier, de Buffon, de Thomas Paine, de William Robertson; a Encyclopédie de Diderot e D'Alembert, e a Wealth of Nations, de Adam Smith; e titulos variados em língua inglesa e francesa sobre história natural, economia, política, viagens, filosofia; nenhum, porém, subversivo (Villalta, 1997: 367).

Embora menores, as bibliotecas de Cipriano Barata e do tenente Hermógenes Pantoja eram mais comprometidas com o perfil revolucionário. Cipriano Barata possuía 74 livros franceses, sendo que três deles eram explicitamente iluministas. Nessas bibliotecas, percebe-se a presença das ideias dos revoltosos 
também nos "boletins sediciosos" publicados em Salvador, em agosto de 1798, ali encontrados. Seja em forma de repúdio ou de aceitação, os textos se fizeram presentes entre letrados e analfabetos. Além dos boletins, também alguns livros e manuscritos encontrados nas bibliotecas de Hermógenes de Aguilar Pantoja e Cipriano Barata de Almeida comprovam que as traduções tiveram um papel importante na propagação das ideias iluministas.

Os manuscritos traduzidos de originais franceses de caráter revolucionário, encontrados nessas bibliotecas, são um exemplo dessa importância das traduções para o movimento baiano. Mattoso (1969) transcreve e comenta os três manuscritos traduzidos encontrados: O Orador dos Estados Gerais de 1789 (1789) a Fala de Boissy d'Anglas (1795) e o Aviso de Petesburgo (1796), além da relação de livros feita pelo escrivão do processo das duas bibliotecas. A pesquisadora observa que, naquela biblioteca, as únicas línguas estrangeiras são o francês e o latim, mas, por vezes, são traduções para o francês de outros idiomas.

Resumindo o primoroso trabalho de Mattoso, pode-se dizer que O Orador dos Estados Gerais (1789) foi o primeiro número de um jornal, que segundo o diretor da censura na França era "uma das brochuras mais audaciosas que poderia ter produzido a licença dos tempos". Publicado anonimamente, depois se identificou o jornalista Jean Louis de Carra, membro da Convenção revolucionária, como seu autor. Traduzido para várias línguas estrangeiras, defendia, entre outras coisas, os direitos do indivíduo, a liberdade de imprensa, a abolição de prisões arbitrárias, que deveriam ser submetidas a um código de leis civis, penais e políticas (Mattoso, 1969: 43-90).

O discurso de Boissy d'Anglas (1795) foi considerado "a declaração do povo francês às nações estrangeiras", feito pelo conde François Antoine de Boissy d'Anglas. Representante da facção moderada, membro da Assembleia Constituinte francesa, Boissy defendia a república como forma de resistência à pressão das monarquias europeias inimigas, e recomendava que seu texto fosse amplamente divulgado e traduzido para todas as linguas (Mattoso, 1969: 97-129).

Por fim, O Aviso de Petersburgo (1796) é um texto de autor desconhecido e de origem obscura, que circulou na França revo-

TradTerm, 17, 2010, p. 31-43 
lucionária, propondo a criação de uma nova Igreja baseada nos princípios dos Direitos Humanos. Há suposições de que seja de origem maçônica, devido seu estilo místico e esotérico (Mattoso, 1969: 130-141).

Os boletins ou pasquins sediciosos são onze textos manuscritos, imbuídos da Ilustração. Encontram-se no acervo do Arquivo Público da Bahia três dos onze manuscritos que foram afixados em Salvador em 12 de agosto de 1798 (Mattoso, 1969: 144). Uma cópia desses documentos também pode ser encontrada na Biblioteca Nacional. Com pequenas diferenças, os pasquins pregavam a igualdade, liberdade e fraternidade, além de exigir um aumento de soldo para soldados e oficiais; elogiavam a França revolucionária e queriam a independência da Bahia:

\footnotetext{
Animai-vos Povo Bahinense que está para chegar o tempo felis de nossa Liberdade; o tempo em que todos seremos irmaons; o tempo em que todos seremos iguaes: sabei que já seguem o partido da Liberdade os seguintes... (Mattoso, 1969: 148)
}

Como referido, vários dos livros da biblioteca de Cipriano José Barata e do Tenente Hermogenes Francisco de Aguillar, que constam dos autos do sequestro, eram traduções, para o português ou para francês, como: Historia das revoluçoens acontecidas no governo da republica romana, em dois tomos, de Vertot D'Auboeuf, tradução portuguesa publicada em 1718; Arte de se tratar a si mesmo nas infermidades venéreas, de Fabreum, tradução portuguesa; Elementos de Euclides (provável tradução portuguesa de Brunelli); Curso de Mathematica por Monsieur Besout (tradução portuguesa feita por José Monteiro da Rocha); Histoire de troubles de l'amérique anglaise (obra não identificada, mas pode ser uma tradução para o francês); Elementos de medicina prática do doutor Guilherme Callem (traduzida para o francês por Bosquillon e não sabemos quem traduziu para o português); Elementos de arithmetica, de Etienne Bezout (traduzida para o português por José Monteiro da Rocha e publicada em Coimbra em 1773) e Livro de vários assentos manuscritos, no qual poderiam ter sido colados trechos da obra Nouvelle Héloïse de Rousseau.

TradTerm, 17, 2010, p. 31-43 
Algumas dessas obras também foram encontradas na biblioteca do cônego Luis Vieira de Mariana e de outros inconfidentes mineiros, como José Resende da Costa, o que não apenas comprova o alcance dos livros franceses na colônia, como seu perfil contestatório. Destaco as seguintes: a tradução do francês de Oeuvres de M. l'Abbé de Condillac, Cours complet de Métaphysique sacrée et profane de Phanjas, Géographie Moderne, de Lacroix, Elementos de medicina prática do doutor Guilherme Callem, Aventuras de Telemaco, de Fénelon, (provavelmente uma tradução do capitão Manoel de Sousa), Dictionnaire historique, que, segundo Frieiro, era de Feller, e a Arte de se tratar a si mesmo nas infermidades venéreas, de Fabreum.

Outras traduções circulavam nesse período na Bahia. Segundo Tavares, "os carmelitas traduziram livros proibidos franceses. O livro Les Ruines ou Méditations sur les revolutions des empires, do Conde de Volney, traduzido pelo professor Francisco Moniz Barreto, circulava [na Bahia] em manuscrito, tendo sido visto pelo pardo e prático de cirurgia José de Freitas Sacoto" (Tavares apud Villalta, 1998: 16).

\section{Conclusão}

Ainda que a oralidade, complementada pela circulação de manuscritos desaparecidos, tenha sido o suporte básico para difusão das ideias nestas sociedades sem imprensa, a presença das ideias iluministas traduzidas é incontestável. Mesmo que em número reduzido, é certo que traduções manuscritas dos textos mencionados difundiram-se entre os participantes dos movimentos mineiro e baiano, reiterando a importância dessa presença. Ou seja, sem tradução, as ideias iluministas não teriam sido discutidas nem divulgadas em panfletos sediciosos, em manuscritos, nas tertúlias, nas reuniões secretas, e não teriam circulado em Minas Gerais e na Bahia, no fim do século XVIII. Há que se reconhecer nesses dois movimentos anticolonialistas o poder dos tradutores na elaboração de um projeto de transformação. Nas duas insurreições da América Portuguesa ora examinadas, a tradução representou "uma arma revolucionária que lançou as bases do constitucionalismo, da democra- 
cia, do federalismo, em suma, os fundamentos dos novos Estados" (Bastin, 2004b).

\section{Referências Bibliográficas}

Autos da Devassa da Inconfidência Mineira. - ADIM vol. 3. 2ª ed. (1980) Brasília: Câmara dos Deputados; Belo Horizonte: Imprensa Oficial de Minas Gerais.

Autos da Devassa da Inconfidência Mineira: complementação documental - ADIM v. 11 (2001). Ouro Preto: Minc-IPHAN-Museu da Inconfidência.

BASTIN, Georges L. (2004) Traduction et révolution à l'époque de l'indépendance hispano-américaine. Meta, vol. 49, n. 3, 2004. http:/ /id.erudit.org/iderudit/009379ar acessado em outubro de 2009.

BASTIN, Georges L. (2004) La cuestión identitaria en la prensa colonial traducida durante el proceso de independencia de Venezuela (18081822). Resumen de proyecto de investigación. HISTAL janeiro de 2004. Disponível em http://www.histal.umontreal.ca/espanol/versionsp. htm. Acessado em 29 de julho de 2009.

FRIEIRO, Eduardo (1957) O diabo na livraria do cônego. Belo Horizonte: Itatiaia.

JANCSÓ, István (1996) Na Bahia, contra o império: história do ensaio de sedição de 1798. São Paulo, Salvador: Hucitec.

JANCSÓ, István (1997) "A Sedução da Liberdade: cotidiano e contestação política no final do século XVIIII". In: NOVAIS, Fernando A. (coord.); SOUZA, Laura de Mello (org.). História da vida privada na América Portuguesa, v. 1. São Paulo: Companhia das Letras.

MATTOSO, Kátia de Queirós (1969) Presença francesa no movimento democrático baiano de 1798. Salvador: Itapuã.

MAXWELLL, Kenneth (1985) A devassa da devassa. São Paulo: Paz e Terra.

VILLALTA, Luiz Carlos (1997) "O que se fala e o que se lê: língua, instrução e leitura”. In: NOVAIS, Fernando A. (coord.).; SOUZA, Laura de Mello (org.). História da vida privada na América Portuguesa, v. 1. São Paulo: Companhia das Letras.

ROCHA, Gabriel. "George Washington in Minas Gerais". Disponivel em http:/ / www.drclas.harvard.edu/revista/articles/view/963 acessado em $18 / 10 / 2009$

TradTerm, 17, 2010, p. 31-43 
SOUZA E SILVA, Joaquim Norberto de (1911) História da conjuração mineira. Rio de Janeiro: Garnier, 1911.

VILLALTA, Luiz Carlos (2006) "O diabo na livraria dos Inconfidentes". Adauto Novaes (org.). Tempo e história, $3^{a}$ ed., 367-395. São Paulo: Companhia das Letras.

VILLALTA, Luiz Carlos (1998) "Bibliotecas Privadas e Práticas de leitura no Brasil Colonial”. Disponivel em www.caminhosdoromance.iel. unicamp.br/.../bibliotecas-br.pdf; tradução de Bibliothéques privées et pratiques de lecture au Brésil colonial. In: MATTOSO, Katia; SANTOS, Idellete Muzar; ROLLAND, Denis. (org.). Naissance du Brésil moderne (1500-1808). Paris: Presses de L’Université de ParisSorbonne, $1^{\mathrm{a}}$ ed., v. 1, pp. 319-336. 